\title{
МОДЕЛЬ ОСАДКОНАКОПЛЕНИЯ В СРЕДНЕМ И ВЕРХНЕМ ДЕВОНЕ НА ТЕРРИТОРИИ ЮГО-ВОСТОКА ВОРОНЕЖСКОЙ АНТЕКЛИЗЫ
}

\author{
А. В. Милаш \\ Воронежский государственный университет \\ Поступила в редакцию 20 ноября 2018 г.
}

\begin{abstract}
Аннотация: основываясь на литолого-фациальном анализе девонских отложений юго-востока Воронежской антеклизы, описаны этапы и стадии осадконакопления. Построены схемы седиментогенеза для основных стадий развития бассейна в каждом этапе. Показано, что при всех общих чертах стадий осадконакопления в каждом этапе они имеют и различия, обусловленные климатическими условиями, интенсивностью тектонических движений, проявляюшихся через рельеф, а также наличием или отсутствием вулканической деятельности. Смена тектонических условий в осадках и стадийность не всегда четко выражены из-за наложения на крупные этапы этапов более высоких порядков. Общая последовательность тектонических движений сохраняется, вместе с тем даже в пределах каждого этапа этот процесс идет неравномерно, что находит прямое отражение в полноте развития той или иной стадии.
\end{abstract}

Ключевые слова: девон, этапы осадконакопления, трансгрессивная стадия, инундаџионная стадия, регрессивная стадия, эмерсивная стадия, схема седиментогенеза.

\section{THE MODEL OF DECOMPOSITION IN THE MIDDLE AND UPPER DEVON IN THE TERRITORY OF THE SOUTHEAST OF THE VORONEZH ANTECLISE}

\begin{abstract}
Devonian deposits of the southeast of the Voronezh anteclise, the main stages of sedimentation are shown. Schemes of sedimentogenesis for the main stages of the basin development in each stage have been constructed. It is shown that with all the general features of the stages of sedimentation in each stage, they also have differences due to climatic conditions, intensity of tectonic movements, manifested through the relief, as well as the presence or absence of volcanic activity. The change of tectonic conditions in the sediments and staging is not always clearly expressed due to the imposition of larger orders of stages at large stages. The overall sequence of tectonic movements is preserved, however, even within each stage, this process is uneven, which is directly reflected in the full development of a particular stage.
\end{abstract}

Keywords: Devonian, sedimentation stages, transgressive stage, inundation stage, regressive stage, emersion stage, sedimentogenesis scheme.

Девонское осадконакопление на ВосточноЕвропейской платформе рассматривалось в работах $[1,2]$, на Воронежской антеклизе - в монографиях [3, 4], для её юго-восточной части - в работе [5], а также освещено во многих других публикациях. Вместе с тем моделирование процессов осадконакопления по основным этапам девонского времени до последнего времени не проводилось. Такая попытка предпринята в настоящей статье.

Прослеживая смену фаций в девонских отложениях юго-востока Воронежской антеклизы, можно выделить следующие крупные этапы осадконакопления, обусловленные закономерной сменой направленности осадочного процесса - эйфельский, живетский, раннесреднефранский и позднефранско-фаменский. Отложения последнего этапа на исследуемой территории в большей своей части представлены континентальными образованиями мамонской песчано-каолиновой толщи [6] и в данной статье рассматриваться не будут. В разрезе каждого из этапов выделяются 4 стадии развития бассейна: трансгрессивная, инундационная, регрессивная и эмерсивная.

В эйфельском этапе стадии начала трансгрессии (соответствующая морсовскому времени) и регрессии (соответствующая черноярскому времени) не рассматриваются, так как отложения этих стратиграфи- 
ческих подразделений практически отсутствуют на исследуемой территории. По данным авторов $[7,8]$, севернее исследуемой территории в морсовское время господствовали континентальные и лагунные условия с аридным климатом, сменившиеся к концу данного времени прибрежно-морскими.

Максимум трансгрессии в эйфельском веке пришелся на мосоловское время (рис. 1а). В целом разрез мосоловских отложений можно разделить на две пачки. Нижняя терригенная пачка соответствует стадии начала трансгрессии, продолжающейся с морсовского времени и характеризует сложную картину палеоре-
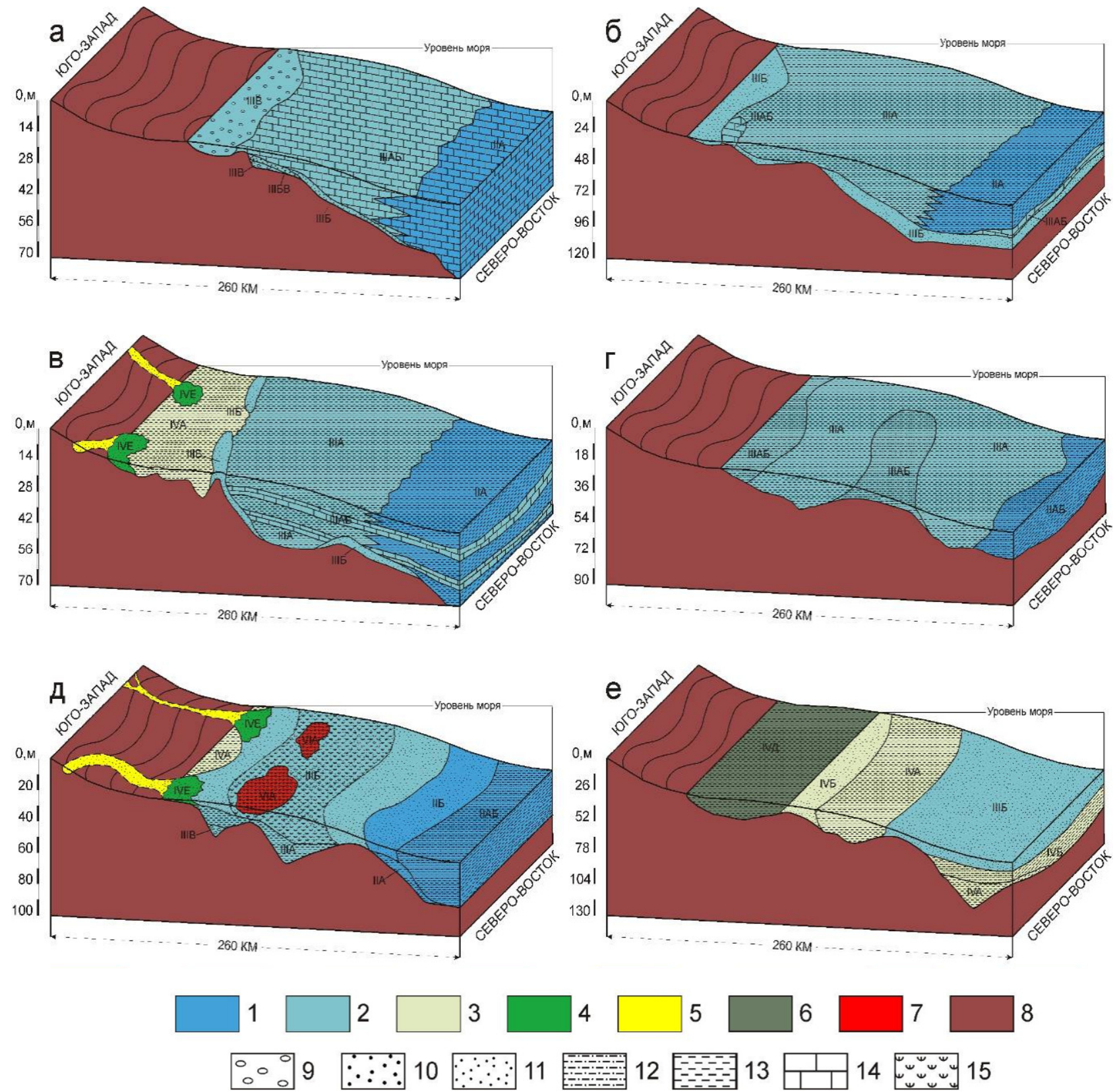

Puc. 1. Схемы седиментогенеза. Время: $a$-мосоловское; $\sigma$-воробьевское; $в$-ардатовское; 2 -муллинское; $\partial-$ ястребовское; $e$ - чаплыгинское. Условные обозначения: 1-6 - фациальные обстановки: 1 - мелководно-морские; 2 - прибрежноморские; 3 - лагунные; 4 - дельтовые; 5 - русловые; 6 - приморских болот; 7 - отложения вулканических построек; 8 - область сноса; 9 - галечники; 10-11 - пески и песчаники: 10 - крупнозернистые; 11 - мелко-среднезернистые; 12 - глинистые алевриты; 13 - аргиллитоподобные глины; 14 - известняки; 15 - примесь туфогенного материала. 
черноярского времени приходится регрессивная стадия, на конец - эмерсивная, в которую происходит размыв ранее сформировавшихся отложений. По данным С. В. Тихомирова [1] предживетским размывом были уничтожены отложения эйфельского века на большей части Воронежской антеклизы.

Трансгрессивная стадия живетского этапа соответствует воробьевскому времени (рис. 1б), которое характеризуется преимущественно прибрежноморским осадконакоплением, главным образом терригенным, в разной степени «разбавленным» карбонатным. Состав пород и их распространение свидетельствуют о начале в воробьевское время морской трансгрессии в юго-западном направлении.

Наличие достаточно мощной толщи терригенных отложений свидетельствует о близости суши, существовавшей довольно продолжительное время и поставлявшей основную массу терригенного материала.

Инундационная стадия живетского этапа осадконакопления пришлась на ардатовское время (рис. 1в). Это наиболее обширная трансгрессия не только для живетского века, но и для всего девона. Большую часть территории затопило эпиконтинентальное море. Данная стадия характеризуется разнообразным, преимущественно мелководно-морским и прибрежноморским осадконакоплением, а также максимальными площадями распространения морских фаций.

Регрессивная стадия для живетского этапа соответствует муллинскому времени (рис. 1г). Отложения данной стадии представлены песчано-алевритоглинистыми породами. Анализ фациальных обстановок показывает, что формирование осадков происходило в обширном мелком морском водоеме с преобладающей слабой гидродинамической активностью водной среды. Об этом свидетельствует превалирование глин, наличие многочисленных железистых оолитов, сферолитов и стяжений сидерита. Для этого времени характерна бедность фауны, которая, повидимому, определялась некоторой опресненностью водного бассейна. Окончание муллинского времени отвечает эмерсивной стадии.

Ястребовское время является стадией начала трансгрессии для ранне-среднефранского этапа осадконакопления (рис. 1д). Оно ознаменовалось проявлением эксплозивной вулканической деятельности. Продукты эксплозивных выбросов оказали существенное влияние на осадконакопление и определили особенный облик пород ястребовской свиты. Отложения представлены преимущественно песчаниками, в том числе вулканогенно-осадочными и вулканомиктовыми, и аргиллитоподобными глинами с подчиненными прослоями алевролитов. Это время прибрежнои мелководно-морского осадконакопления, терригенного, на юге территории с большим количеством вулканогенного материала.

В начале чаплыгинского времени (рис. 1е) произошла локальная регрессия, на что указывает большое количество осадков, накопление которых про- исходило в опресненных мелководных и относительно глубоководных лагунах, а также в условиях приморских болот. Конец чаплыгинского времени ознаменовался новой трансгрессией, на что указывает смена вверх по разрезу переходных фаций прибрежно-морскими. Присутствие аллохтонного растительного детрита, преимущественно кварцевый состав пород и отсутствие грубообломочных разностей указывает на выравненность суши, наличие на ней кор выветривания.

\section{Выводы}

В целом для трансгрессивной и регрессивной стадий характерно относительное разнообразие литологических типов пород в разрезе и по простиранию. Инундационная стадия характеризуется компенсируемым осадконакоплением и максимальными площадями распространения мелководно-морских отложений и относительной однородностью разреза на значительной территории. Эмерсивная - преобладанием процессов размыва над процессами осадконакопления.

Но при всех общих чертах той или иной стадии каждого этапа, они имеют и различия, обусловленные тем, что процесс тектонического развития сопровождается возникновением сингенетических структур (поднятий и впадин), что отражается на фациальном облике формирующихся осадков. При этом для каждого этапа характерна своя специфика, обусловленная его климатическими условиями, интенсивностью тектонических движений, проявляющихся через рельеф, наличием или отсутствием вулканической деятельности. Геодинамические процессы протекают непрерывно, однако смена тектонических условий в осадках и стадийность не всегда четко выражены из-за наложения на крупные этапы этапов более высоких порядков [1]. Общая последовательность тектонических движений сохраняется (погружение сменяется воздыманием), так же как и общая последовательность стадий развития, присущая каждому этапу.

Вместе с тем даже в пределах каждого из них этот процесс идет неравномерно, что находит прямое отражение в полноте развития той или иной стадии. На общем фоне погружений в трансгрессивную, да и в инундационную стадии могут происходить кратковременные воздымания, что можно наблюдать на примере изменения фаций чаплыгинского времени, иногда сопровождаемые перерывом в осадконакоплении и размывом сформировавшихся ранее отложений. Вследствие этого в разрезе появляются нетипичные для данной стадии отложения и следы перерывов. Особенно четко это наблюдается в инундационной стадии, когда в однообразной толще преимущественно глинистых пород, характерных для этой стадии, появляются песчаные разности, что особенно проявляется в ардатовское время, характеризующееся наибольшей трансгрессией в девоне на рассматриваемой территории. Но при дальнейшем изучении и ис- 
пользовании иерархии более высоких порядков, в каждой из стадий можно будет выделить подстадии, которым будут соответствовать эти «нетипичные» образования.

Исследование выполнено при финансовой поддержке РФФИ в рамках научного проекта № 18-3500115 мол_а

The reported study was funded by RFBR according to the research project № 18-35-00115 мол_a

\section{ЛИТЕРАТУРА}

1. Тихомиров, С. В. Этапы осадконакопления девона Русской платформы и общие вопросы развития и строения стратисферы / С. В. Тихомиров. - М.: Недра, 1995. - 445 с.

2. Геологические формации осадочного чехла Русской платформы / Н. С. Иголкина [и др.]. - Л.: Недра, 1986. - 168 с. 3. Девон Воронежской антеклизы и Московской синеклизы / Г. Д. Родионова [и др.]. - М., 1995. - 265 с.

4. Объяснительная записка к атласу фациальных карт Воронежской антеклизы / А. Д. Савко [и др.]. // Труды научно-

Воронежский государственный университет, НИИ Геологии

Милаш Алексей Васильевич, ведущий инженер, кандидат геолого-минералогических наук

E-mail:pirit86@yandex.ru

Тел.: 89030305147 исследовательского института геологии Воронеж. гос. унта. - Вып. 20 - Воронеж: Изд-во ВГУ, 2004. - 107c.

5. Милаш, А. В. Литология девонских отложений юговостока Воронежской антеклизы / А. В. Милаш, А. Д. Савко // Труды научно-исследовательского института геологии Воронеж. гос. ун-та. - Вып. 100 - Воронеж: Изд-во ВГУ, 2017. - 131c.

6. Савко, А. Д. Литология и полезные ископаемые мамонской песчано-каолиновой толщи Воронежской антеклизы / А. Д. Савко, С. В. Мануковский, Л. Т. Шевырев // Труды научно-исследовательского института геологии Воронеж. гос. ун-та. - Вып. 53. - Воронеж., 2009. - 112 с.

7. Мануковский, С. В. Морсовские отложения Воронежской антеклизы / С. В. Мануковский // Вестник Воронеж. гос. ун-та. - Сер.: Геология. - Воронеж. - 2000. - № 9. - С. $66-75$.

8. Литология и фации донеогеновых отложений Воронежской антеклизы / А. Д. Савко [и др.]. // Труды научноисследовательского института геологии Воронеж. гос. унта. - Вып. 3. - Воронеж: Изд-во ВГУ, 2001. - 201 с.

Voronezh State University,

Scientific Research Institute of Geology

Milash A. V., the lead engineer, Candidate of Geological and Mineralogical Sciences

E-mail: pirit86@yandex.ru

Tel.: 89030305147 